Acta vet. scand. $1974,15,366-380$.

From the Department of Food Hygiene, Veterinary College of Norway, Oslo.

\title{
THE SUITABILITY OF SOME MEDIA AND PEPTONES FOR SULFONAMIDE TESTING*
}

\author{
By \\ Roar Gudding
}

GUDDING, ROAR: The suitability of some media and peptones for sulfonamide testing. Acta vet. scand. 1974, 15, 366-380. - The content of p-aminobenzoic acid and folic acid has been determined in some media and peptones, and the sensitivity of Bacillus megaterium, cultivated on these substrates, towards sulfonamides has been examined.

The concentrations of p-aminobenzoic acid and folic acid should be as low as possible in suitable substrates, but other factors are also of importance. The presence of antagonists towards folic acid has been demonstrated in some media, and the consequences of these inhibitors are discussed.

Three of the media (Paper Disc Method-Antibiotic Sensitivity Medium, AB Biodisk; Sulphonamide Antagonist Free Medium, Mast Laboratories; and Mueller Hinton, Difco Laboratories) seem to be satisfactory for the determination of the resistance of bacteria towards sulfonamides. The application of Acetobacter medium is suggested for the detection of rest concentrations of sulfonamides in foodstuffs.

detection of sulfonamide residues; p-aminobenzoic acid; folic acid.

Determination of the sensitivity of bacteria towards sulfonamides requires bacterial media without, or with only traces of sulfonamide antagonists. For the detection of small concentrations of sulfonamides in milk and meat this requirement is still more important.

The medium described by Mueller \& Hinton (1941) for the isolation of gonococci and meningococci has, for many years, been used for antibacterial susceptibility testing, and it is even recommended as a reference medium for this purpose (Ericsson $\&$ Sherris 1971). The Mueller Hinton medium has also been applied for the detection of antimicrobial agents, including sulfon-

* This investigation was supported by the Agricultural Research Council of Norway. 
amides, in milk (Read et al. 1971, Gudding \& Hellesnes 1973) and in meat (Yndestad 1973).

When the Mueller Hinton medium is used for detection of sulfonamides, bacterial growth is not completely inhibited by small amounts of sulfonamides, and consequently the inhibition zones are not distinct (Gudding \& Hellesnes). Rose \& Snyder (1971) found that the Mueller Hinton medium contained antisulfa components and recommended a more defined, synthetic medium for sensitivity testing of Staphylococcus aureus and Gram-negative bacteria.

During the last few years, new media have been produced which, according to the manufacturers, are free from sulfonamide antagonists and contain necessary growth factors for pathogenic bacteria (Anon., Mast Laboratories 1972, Anon., AB Biodisk 1973).

Woods (1940) showed that p-aminobenzoic acid ( $\mathrm{p}-\mathrm{AB}$ ) could antagonize the bacterial inhibitory effect of sulfanilamide. Later research, reviewed by Hitchings \& Burchall (1965), has revealed that $\mathrm{p}-\mathrm{AB}$ is essential for the synthesis of dihydrofolic acid, which itself is a precursor for coenzymes in the synthesis of purines and other biological substances with methyl or formyl groups.

It was, therefore, reasonable to believe that p-aminobenzoic acid and folic acid (FA) were important factors for the suitability of media used for detection and susceptibility testing of sulfonamides. The aim of the present work was to determine quantitatively the amounts of $\mathrm{p}-\mathrm{AB}$ and FA in different media/ peptones and in fractions of such substrates, and to determine the lowest detectable concentrations of sulfonamides using these substrates, with and without the addition of $\mathrm{p}-\mathrm{AB}$ and FA.

\section{MATERIAL AND METHODS}

Media. The following media/peptones were included in this investigation: Mueller Hinton (MH) broth (Difco* 0757-01), Bacto-peptone (Difco 0118-01), Proteose peptone No. 3 (Difco 0122-02), Neopeptone (Difoo 0119-01), Yeast extract (Difco 0127-01), Bacteriological peptone (Oxoid** C 37), Lab-Lemco Powder (Oxoid C 29), Pepton, special "Orthana" (A/S Orthana**), Paper Disc Method-Antibiotic

* Difco Laboratories, Inc., Detroit, Michigan, USA.

* Oxoid Ltd., London, England.

** A/S Orthana Kemisk Fabrik, Copenhagen, Denmark. 
Sensitivity Medium (PDM) (AB Biodisk*). Orthana peptone is prepared by enzymatic hydrolysis of casein, the other peptones are hydrolysates of different proteinaceous materials, mostly meat (Anon., Difco Manual 1953, Anon., Oxoid Manual 1969, Anon., A/S Orthana Kemisk Fabrik 1973). In addition, the suitability of Sulphonamide Antagonist Free Medium (SAF) (Mast Laboratories* *) for the detection of sulfonamides was tested, but due to late delivery this medium was not included throughout the investigation. The latter medium and PDM were available only with agar added to the dehydrated media.

Quantitative assays of $p-A B$ and $F A$. These investigations were performed by microbiological methods using bacteria with absolute dependence on $\mathrm{p}-\mathrm{AB}$ and $\mathrm{FA}$ as growth factors.

p-aminobenzoic acid. A method described by Landy \& Dicken (1942), based on the growth response of Acetobacter suboxydans ATCC $^{* *} 621$ for $\mathrm{p}-\mathrm{AB}$, was used with a minor modification. The basic medium contained the following ingredients: Acid hydrolysed casein A \& H (Allen \& Hanburys $\dagger$ ), 6 g; Mannitol, 20 g; Tryptophan, 200 mg; Cystine, $150 \mathrm{mg} ; \mathrm{KH}_{2} \mathrm{PO}_{4}, 1 \mathrm{~g} ; \mathrm{K}_{2} \mathrm{HPO}_{4}, 1 \mathrm{~g} ; \mathrm{MgSO}_{4} .7 \mathrm{H}_{2} \mathrm{O}, 400 \mathrm{mg}$; $\mathrm{NaCl}, 20 \mathrm{mg} ; \mathrm{FeSO}_{4} \cdot 7 \mathrm{H}_{2} \mathrm{O}, 20 \mathrm{mg}$; $\mathrm{MnSO}_{4} \cdot 2 \mathrm{H}_{2} \mathrm{O}, 20 \mathrm{mg}$; Calcium pantothenate, $2 \mathrm{mg}$; Nicotinic acid, $2 \mathrm{mg}$. Distilled water was added to $1000 \mathrm{ml}$ and the $\mathrm{pH}$ adjusted to 6.0 . Filtration was necessary to clarify the broth. The medium is in this paper called Acetobacter medium and it differs from the basic medium of Landy \& Dicken by the replacement of glycerol with mannitol as carbohydrate source. Acetobacter suboxydans is an obligate aerobe organism, and for that reason the samples were incubated in $50 \mathrm{ml}$ Erlenmeyer flasks instead of ordinary test tubes. Incubation conditions were $26^{\circ} \mathrm{C}$ for $44 \mathrm{hrs}$.

Folic acid. The procedures for the quantitative determination of FA have been described by several authors (Eigen \& Shockman 1963, Cooperman 1971, Tsukahara \& Yamada 1971). In this work Streptococcus faecalis ATCC 8043 was used as test organism and Folic Acid Assay PGA Broth (BBL ${ }^{\dagger \dagger}$ 11267) as test medium. The samples were incubated in the test tubes for $20 \mathrm{hrs}$. at $37^{\circ} \mathrm{C}$.

Stock cultures. Acetobacter suboxydans was cultured on mannitol agar (Yeast extract, $5 \mathrm{~g}$; Bacto-peptone, $3 \mathrm{~g}$; mannitol, $25 \mathrm{~g}$; agar, $15 \mathrm{~g}$; distilled water, $1000 \mathrm{ml}$ ). The test organism used for susceptibility testing of sulfonamides, Bacillus megaterium ATCC 9885, was grown on the Mueller Hinton agar. Both of these bacteria were harvested directly from the media before use. Streptococcus faecalis was stored on nutrient agar with $7 \%$ defibrinated blood and subcultivated daily on Lactobacillus broth AOAC (Difco 0901-15).

* AB Biodisk, Stockholm, Sweden.

* Mast Laboratories, Liverpool, England.

* * American Type Culture Collection, Rockville, Maryland, USA.

$\dagger$ Allen \& Hanburys Ltd., London, England.

†† Baltimore Bacteriological Laboratories, Cockeysville, Maryland, USA. 
Dilutions and standards. In most cases, $1 \%$ dilutions of all peptones and media were used in the quantitative determinations of $\mathrm{p}-\mathrm{AB}$ and FA, and in the sulfonamide sensitivity tests. PDM and SAF (neither of them available without agar) were used in the susceptibility tests according to the prescriptions of the manufacturers. The standards of $\mathrm{p}-\mathrm{AB}$ and $\mathrm{FA}$ were prepared in suitable dilutions using distilled water and $0.05 \mathrm{M}$ phosphate buffer, respectively, as diluent. The standard solutions were stored in a refrigerator. Since only one sulfonamide was used, the concentrations of the sulfanilamide standards are given in p.p.m. instead of $\mu \mathrm{M}$ (1 p.p.m. equals $5.8 \mu \mathrm{M})$.

Turbidimetric tests. Turbidimetric readings were made in a Hilger * photometer with a filter corresponding to a wave length of $610 \mathrm{~nm}$. Standard dilutions were included in all test series.

Agar diffusion methods. In addition to the turbidimetric methods used for the accurate determinations of $\mathrm{p}-\mathrm{AB}$ and $\mathrm{FA}$, agar diffusion methods were also used for rapid examinations of the two components, and for comparisons of the methods. The basic medium was diluted with an equal amount of distilled water, and Special AgarNoble (Difco 0142-02) was added to a concentration of $1.5 \%$ before autoclaving. One day old cultures of the test bacteria were washed three times in saline and mixed with the medium after cooling to $45^{\circ} \mathrm{C}$. Standard dilutions of $\mathrm{p}-\mathrm{AB}$ and FA were included for comparison in all the agar diffusion tests. Testing for antagonism towards p-AB and FA in the various media/peptones was also performed by the agar diffusion method. The test media (Acetobacter medium and Folic Acid Assay PGA Broth) were supplemented with $2 \mu \mathrm{g}$ p-AB and $1 \mu \mathrm{g}$ FA, respectively, per $100 \mathrm{ml}$ medium before autoclaving. Sulfonamide sensitivity tests were performed by the agar diffusion method using Bacillus megaterium ATCC 9885 as a test organism (Gudding \& Hellesnes 1973). In all agar diffusion tests, the samples were applied in circular wells of $10 \mathrm{~mm}$ diameter in an agar layer which was 2 $\mathrm{mm}$ thick. This method of sample application was preferred to the use of metal cylinders placed on the agar surface, on the basis of preliminary investigations which indicated that the zones of growth, or inhibition, were larger around the wells than the cylinders. In order to avoid growth of unspecific bacteria in the wells of Acetobacter medium all samples were filtered through a Millipore filter $0.45 \mu$.

Gel filtration. Fractionation of media and peptones was carried out by gel filtration on a Sephadex G $50^{* *}$ column, $1.8 \times 85 \mathrm{~cm}$. Solutions of $0.5 \mathrm{~g}$ medium/peptone in distilled water were applied onto the column. The procedures for preparation, packing, stabilization and sample application were performed according to the descriptions of the manufacturer (Anon., Pharmacia 1972). The operating pressure was $18 \mathrm{~cm}$, which gave a flow rate of about $0.3 \mathrm{ml}$ per min. Distilled

* Hilger \& Watts, Rank Precision Industries Ltd., London, England.

* Pharmacia, Uppsala, Sweden. 
water was used as an eluant. Blue dextran and $\mathrm{K}_{2} \mathrm{CrO}_{4}$ were utilized for estimations of molecular weights. The fractions were tested for $\mathrm{p}-\mathrm{AB}$ and $\mathrm{FA}$ activity and antagonism by the agar diffusion method as described above.

\section{RESULTS}

In most of the media/peptones, the content of $\mathrm{p}-\mathrm{AB}$ was of the same magnitude, $1-3 \mu \mathrm{g} / \mathrm{g}$ dehydrated medium (Table 1 ). It is noticeable that the concentration of $\mathrm{p}-\mathrm{AB}$ in $\mathrm{PDM}$ was of the order of $2.8 \mu \mathrm{g} / \mathrm{g}$. Yeast extract, containing $75 \mu \mathrm{g} \mathrm{p}-\mathrm{AB} / \mathrm{g}$, seemed to be a very rich source of $\mathrm{p}-\mathrm{AB}$.

The content of FA was especially low in PDM, MH and low in Lab-Lemco Powder (Table 2). The turbidimetric assays of

Table 1. The content of p-aminobenzaic acid in the media/peptones assayed by the turbidimetric method and the agar diffusion method.

\begin{tabular}{lcc}
\hline Medium/peptone & $\begin{array}{c}\text { Turbidimetric method } \\
\mu \mathrm{g} / \mathrm{g}\end{array}$ & $\begin{array}{c}\text { Agar diffusion method } \\
\mu \mathrm{g} / \mathrm{g}\end{array}$ \\
\hline Mueller Hinton broth (MH) & 1.5 & 0.8 \\
Bacto-peptone & 1.6 & 0.7 \\
Proteose peptone No. 3 & 1.9 & 0.8 \\
Neopeptone & 1.8 & 0.7 \\
Yeast extract & 75 & 50 \\
Bacteriological peptone & 1.5 & 1.0 \\
Lab-Lemco Powder & 3.0 & 0.8 \\
Orthana peptone & 1.0 & 0.6 \\
Paper Disc Method- & & 0.8 \\
Antibiotic Sensitivity Medium (PDM) & 2.8 & \\
\hline
\end{tabular}

T a ble 2. The content of folic acid in the media/peptones assayed by the turbidimetric method and the agar diffusion method.

\begin{tabular}{lcc}
\hline Medium/peptone & $\begin{array}{c}\text { Turbidimetric method } \\
\mu \mathrm{g} / \mathrm{g}\end{array}$ & $\begin{array}{c}\text { Agar diffusion method } \\
\mu \mathrm{g} / \mathrm{g}\end{array}$ \\
\hline Mueller Hinton broth (MH) & 0.12 & 0.12 \\
Bacto-peptone & 0.28 & 1.3 \\
Proteose peptone No. 3 & 1.40 & 5.0 \\
Neopeptone & 0.20 & 0.25 \\
Yeast extract & 0.77 & 1.0 \\
Bacteriological peptone & 0.21 & 0.80 \\
Lab-Lemco Powder & 0.12 & 0.20 \\
Orthana peptone & 0.10 & 0.65 \\
Paper Disc Method- & & \\
Antibiotic Sensitivity Medium (PDM) & 0.09 & $<0.10$ \\
\hline
\end{tabular}


Orthana peptone indicated a low content of FA also in this peptone, disagreeing with the results of the assay by the agar diffusion method. Similar differences existed for Bacteriological peptone, Bacto-peptone and Proteose peptone No. 3.

As shown in Table 3, sulfanilamide concentrations of $\mathbf{7 . 5}$ p.p.m. (43.5 $\mu \mathrm{M}$ ) (in water) could be detected using MH, PDM, and SAF. The inhibition zones in PDM were, however, a little more distinct than those in MH and SAF, because of more complete inhibition of bacterial growth. Using Acetobacter medium a concentration of 2.5 p.p.m. $(14.5 \mu \mathrm{M})$ gave detectable zones.

T a b l e 3. Lowest detectable concentrations of sulfanilamide using different media, and Bacillus megaterium as test organism.

\begin{tabular}{lc}
\hline & p.p.m. \\
\hline Mueller Hinton (MH) & 7.5 \\
Bacto-peptone & 50 \\
Proteose peptone No. 3 & 50 \\
Neopeptone & 50 \\
Mueller Hinton + 0.1 \% Yeast extract & 50 \\
Bacteriological peptone & 50 \\
Mueller Hinton + 1 \% Lab-Lemco Powder & 30 \\
Paper Disc Method-Antibiotic Sensitivity Medium (PDM) & 7.5 \\
Sulphonamide Antagonist Free Medium (SAF) & 7.5 \\
Acetobacter medium & 2.5 \\
\hline
\end{tabular}

Although there were small differences in the clarity and diameters of the zones, it was possible to demonstrate the presence of 50 p.p.m. $(290 \mu \mathrm{M})$ of sulfanilamide using all the other peptones. The effect of Yeast extract and Lab-Lemco Powder was shown by adding these nutritive components to $\mathrm{MH}$ to a final concentration of $0.1 \%$ and $1 \%$, respectively (Fig. 1). Yeast extract gave a distinct reduction in the sulfonamide sensitivity in the MH medium and the same effect, although more moderate, could be seen after the addition of Lab-Lemco Powder. The inhibition zones on all these substrates were, even at high concentrations of sulfonamide like 500 p.p.m. $(2.9 \mathrm{~m} \mathrm{M})$, more or less diffuse because of incomplete bacterial inhibition.

The addition of $2 \mu \mathrm{g}$-AB per $100 \mathrm{ml}$ medium reduced the sensitivity in all media. The curves showing diameters of inhibition zones as functions of sulfanilamide concentration using $\mathbf{M H}$, PDM and Bacto-peptone are presented in Figs. 2, 3 and 4. The 

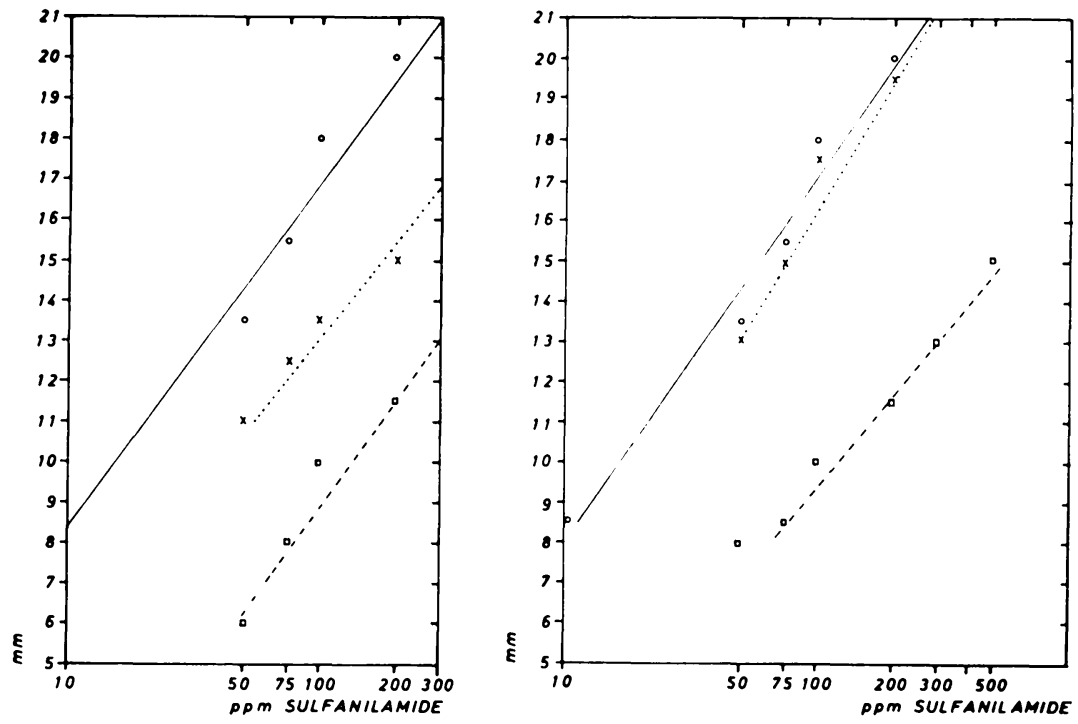

Figure 1. Diameters of inhibition zones as a function of sulfanilamide concentration on Mueller Hinton (MH) $\mathrm{O}-\mathrm{o}$, Mueller Hinton $+1 \%$ Lab-Lemco Powder $\times \ldots \times$ and Mueller Hinton $+0.1 \%$ Yeast extract

Figure 2. Diameters of inhibition zones as a function of sulfanilamide concentration on Mueller Hinton (MH) o- o, Mueller Hinton $+2 \mu \mathrm{g}-\mathrm{AB} /$ $100 \mathrm{ml} \square-\ldots-\square$ and Mueller Hinton $+1 \mu \mathrm{gF} / 100 \mathrm{ml} \times \ldots \times$.

results for the other peptones were similar to those for Bactopeptone. The zones were, for all the media, of the same clarity as the zones without the addition of $\mathrm{p}-\mathrm{AB}$. The sensitivity of Acetobacter medium was reduced more than that of $\mathrm{MH}$ and PDM (Fig. 5). Using Acetobacter medium enriched with p-AB, 75 p.p.m. $(435 \mu \mathrm{M})$ of sulfanilamide was hardly detected and concentrations of 200 p.p.m. ( $1.2 \mathrm{~m} \mathrm{M})$ gave zones of similar size to those for 50 p.p.m. $(290 \mu \mathrm{M})$ using $\mathrm{MH}$ enriched with p-AB.

Folic acid, in a concentration of $1 \mathrm{~kg}$ per $100 \mathrm{ml}$ medium, also caused a reduction in sulfonamide sensitivity (Figs. 2, 3, 4), but to a smaller extent than the sensitivity reduction by $\mathrm{p}-\mathrm{AB}$. The addition of FA gave, however, more diffuse zones in all the media, and the greatest reductions in sulfonamide sensitivity were observed in the media with the most diffuse zones before FA addition. The inhibition zones of PDM and $\mathrm{MH}$ were only slightly reduced. 


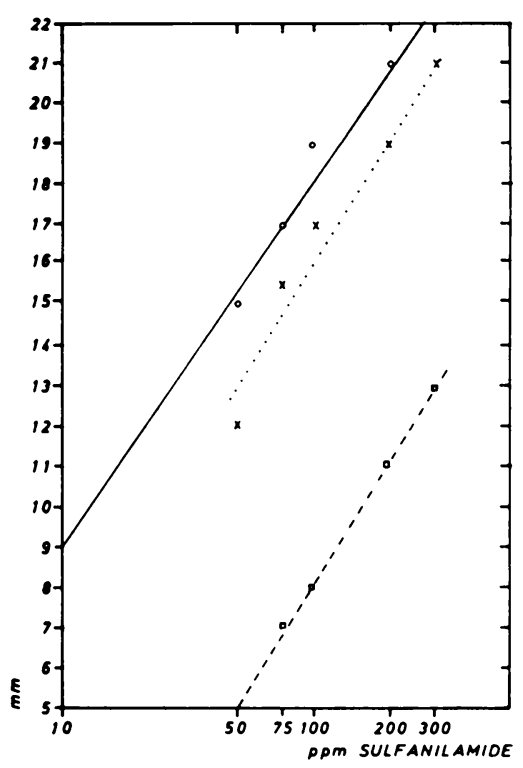

F igure 3. Diameters of inhibition zones as a function of sulfanilamide concentration on Paper Disc Method-Antibiotic Sensitivity Medium (PDM) $0-0, \mathrm{PDM}+2 \mu \mathrm{g} \mathrm{p}-\mathrm{AB} / 100$ $\mathrm{ml} \square-\cdots \square$ and PDM $+1 \mu \mathrm{g}$ FA $/ 100 \mathrm{ml} \times \ldots \times$.

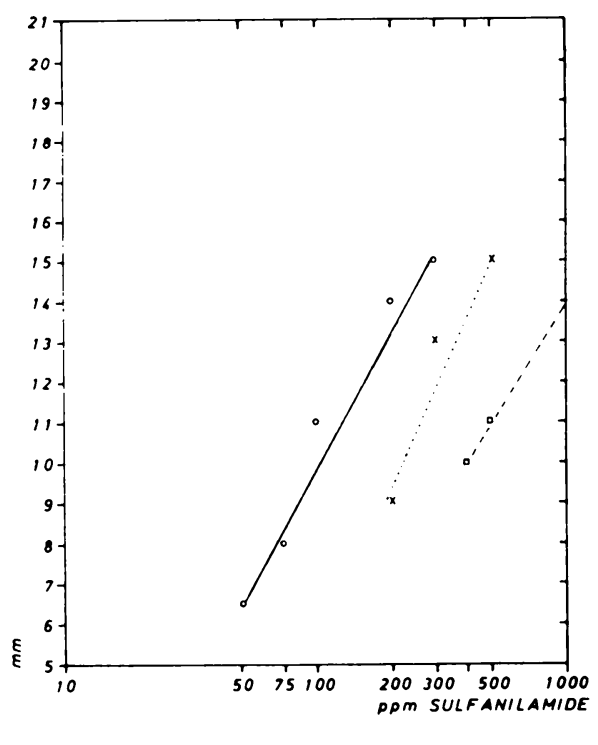

Figure 4. Diameters of inhibition zones as a function of sulfanilamide concentration on Difco Bacto-peptone o- o, Bacto-peptone $+2 \mu \mathrm{g} \mathrm{p}-\mathrm{AB} / 100$ $\mathrm{ml} \square-\ldots-\square$ and Bacto-peptone $+1 \mu \mathrm{g} \mathrm{FA} / 100 \mathrm{ml} \times \ldots \times \times$.

The assays by the agar diffusion method for the quantitative analysis of $\mathrm{p}-\mathrm{AB}$ and $\mathrm{FA}$ in the media/peptones revealed that the growth zones in the solid test media produced by $\mathrm{p}-\mathrm{AB}$ and FA were separated, more or less distinctly, into an inner and outer zone. This effect occurred, to varying degrees, with most media on the FA testing medium.

The application of solutions of the media/peptones onto the plates with test medium (Acetobacter medium and Folic Acid Assay PGA broth) to which $\mathrm{p}-\mathrm{AB}$ and FA had been added, respectively, revealed zones with reduced bacterial growth around some of the wells. These zones could be seen on the FA test medium with nearly all the substrate solutions. Compared with the heavy growth on the rest of the agar, the zones were fairly distinct, especially when the plates were observed with oblique lighting and against a dark background. The appearance of the zones using $1 \%$ solutions of the media was a uniform reduction 


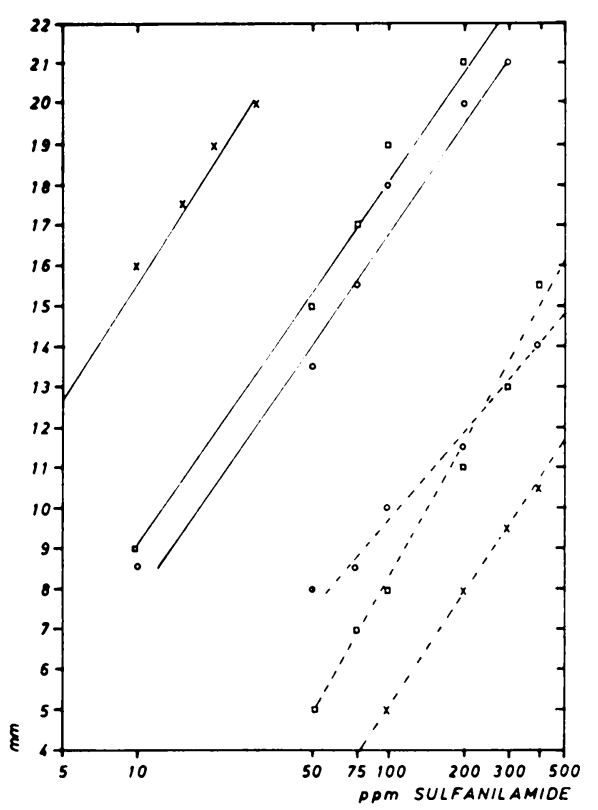

F ig u re 5. Diameters of inhibition zones as a function of sulfanilamide concentration on Mueller Hinton (MH) $0-0$, Mueller Hinton $+2 \mu \mathrm{g} \mathrm{p}-\mathrm{AB} / 100 \mathrm{ml} \mathrm{o---o,} \mathrm{Paper} \mathrm{Disc} \mathrm{Method-Antibiotic} \mathrm{Sen-}$ sitivity Medium (PDM) $\square-\square$, PDM + $2 \mu \mathrm{g} \mathrm{p}-\mathrm{AB} / 100 \mathrm{ml} \square-\ldots \square$, Acetobacter medium $\times \longrightarrow$ and Acetobacter medium $+2 \mu \mathrm{g}$ p$\mathrm{AB} / 100 \mathrm{ml} \times \cdots \times-$

of growth. More concentrated solutions produced larger zones, but the growth inhibition was neutralized near the wells.

The largest zones were produced by Bacteriological peptone, Proteose peptone No. 3, Neopeptone and MH, while the zone of PDM was the smallest. Bacto-peptone did not produce any zone with diminished growth.

The fractionation of the substrates by gel filtration was followed by quantitative determinations of $\mathrm{p}-\mathrm{AB}$ and $\mathrm{FA}$ in the fractions. The results for $\mathrm{MH}$ and Bacteriological peptone are shown in Fig. 6. In $\mathrm{MH}$, the peak of $\mathrm{p}-\mathrm{AB}$ appeared before that of FA. Small amounts of FA could be detected before the major part of FA was eluted. Several media showed a similar elution pattern to $\mathrm{MH}$, including Bacto-peptone, Orthana peptone, Neopeptone and Lab-Lemco Powder. The elution pattern of $\mathrm{p}-\mathrm{AB}$ in Bacteriological peptone was, apart from quantitative differences, like that of $\mathrm{MH}$. 


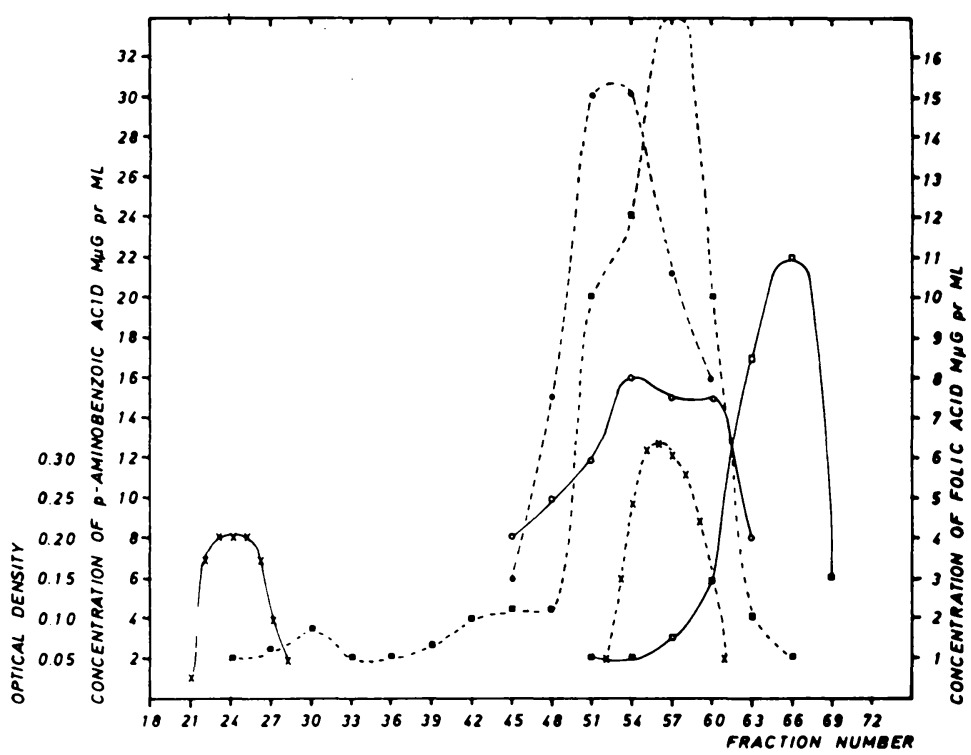

Fig u re 6. Distribution pattern of $p-A B$ and $F A$ in fractions of Mueller Hinton (MH) and Bacteriological peptone separated by gel filtration on Sephadex G 50. p-AB in Mueller Hinton o- 0 , FA in Mueller Hinton $\square-\square$, p-AB in Bacteriological peptone $\bullet . .$. , FA in Bacteriological peptone .... Blue dextran $(620 \mathrm{~nm})$ $\times \longrightarrow \times$ and $\mathrm{K}_{2} \mathrm{CrO}_{4}(410 \mathrm{~nm}) \times-\cdots \times$.

In Bacteriological peptone, however, FA was distributed in all the fractions, with a maximum at $114 \mathrm{ml}$ (fraction number 57). In Proteose peptone No. 3 and PDM, FA activity could be detected at an elution volume of $70 \mathrm{ml}$ (fraction number 35 ), otherwise these substrates showed a similar distribution of FA to Bacteriological peptone.

Antagonists of FA appeared in the last fractions of Proteose peptone No. 3, Bacteriological peptone, $\mathrm{MH}$, Neopeptone and Orthana peptone. The activity of the antagonists is indicated by the order of the substrates mentioned, as Proteose peptone No. 3 showed the largest and most distinct inhibition zones. The molecular weights of the inhibitory substances were estimated to be less than 500 .

Antagonism of $\mathrm{p}-\mathrm{AB}$ could also be detected in some fractions of a few media, but the zones were too weak to be considered further. 


\section{DISCUSSION}

This investigation indicates that the media used for the determination of bacterial susceptibility towards sulfonamides and for the detection of sulfonamide residues are essential for the accuracy and sensitivity of the tests.

A comparison and evaluation of the turbidimetric and agar diffusion methods for quantitative assays of $\mathrm{p}-\mathrm{AB}$ and FA based on the results of this work, indicate that the turbidimetric method should be used for accurate analysis.

Although agar diffusion methods may give a good impression of the quantity of growth substances, other factors will influence the diffusion of the components and, consequently, the result. A comparison of the results of the two methods generally shows lower results for $\mathrm{p}-\mathrm{AB}$ and higher values for $\mathrm{FA}$ in some media in the agar diffusion test. Table 2 shows that Onthana peptone and to a lesser degree Bacto-peptone, Bacteriological peptone and Proteose peptone No. 3 exhibit differences between the two methods of analysis which may be due to substances with general or specific inhibitory effects giving distortion of the turbidimetric results.

The finding, in this investigation, of a high content of $\mathrm{p}-\mathrm{AB}$ in Yeast extract is in fairly good accordance with the results of Landy \& Dicken (1942) who found $102 \mu \mathrm{g} / \mathrm{g}$ and $40 \mu \mathrm{g} / \mathrm{g}$, respectively, in brewers' yeast and yeast extract.

The suitability of a medium/peptone for testing for sulfonamide residues depends on different factors. Although the results of the p-AB analyses, with the exception of Yeast extract, were of approximately the same size, this substance is of importance for the suitability of the media. The addition of $\mathrm{p}-\mathrm{AB}$ in small concentrations to the substrates, and the addition of $0.1 \%$ Yeast extract to $\mathrm{MH}$ medium establish that the $\mathrm{p}-\mathrm{AB}$ content should be as low as possible in a medium used for sulfonamide testing.

The quantitative FA analyses revealed that the values of FA in Proteose peptone No. 3 were distinctly higher than those of the other media. A difference in sensitivity corresponding to this distinction has not been demonstrated. The addition of FA to the media/peptones caused more diffuse zones of growth inhibition even in areas with high concentrations of sulfonamides.

Acetobacter suboxydans, requiring $\mathrm{p}-\mathrm{AB}$ for growth, could not use FA as a substitute for $\mathrm{p}-\mathrm{AB}$. This fact is probably due to the inability to transport FA into the cell (Weygand et al. 1956). 
In the present study, it has been shown that Bacillus megaterium could use p-AB and FA as alternative growth factors, indicating that exogenously supplied folates can be incorporated into the cells.

The conclusions to be drawn from these results are in conformity with the established view that sulfonamides reduce the growth of bacteria by competitive inhibition with $\mathrm{p}-\mathrm{AB}$, and that folic acid gives a non-competitive reversal of the inhibition because it is a product of the reaction which the sulfonamides inhibit.

The suitability of PDM and MH for the testing of sulfonamides is almost equal, with the former as the most favourable due to more distinct inhibition zones. SAF seemed to be of the same quality as $\mathrm{MH}$ with regard to suitability for sulfonamide testing. The simple medium used in the $\mathrm{p}-\mathrm{AB}$ analysis, Acetobacter medium, was superior to all these media as a substrate for detecting remains of sulfonamides. This medium, giving a heavy growth of Bacillus megaterium, did not support the growth of other test bacteria such as Sarcina lutea. The fact that addition of $\mathrm{p}-\mathrm{AB}$ to this medium reduced the sensitivity relatively more than did a corresponding addition to $\mathrm{MH}$ and PDM, indicates the possible presence of inhibitors in MH and PDM media.

The results of the gel filtration experiment suggest that most of the $\mathrm{p}-\mathrm{AB}$ and $\mathrm{FA}$ exists in a free form, but the appearance of $\mathrm{p}-\mathrm{AB}$ in earlier fractions than $\mathrm{FA}$, and a part of it at a lower elution volume than $\mathrm{K}_{2} \mathrm{CrO}_{4}$ indicates that $\mathrm{p}$ - $\mathrm{AB}$ is partially bound to peptides or other compounds. In Bacteriological peptone and, to a lesser degree, in Proteose peptone No. 3 and PDM, FA is bound to high molecular weight substances, probably proteins and peptides. Ford et al. (1969) have shown that FA is bound to proteins in cow's milk.

A possible binding of $\mathrm{p}-\mathrm{AB}$ or $\mathrm{FA}$ does not seem to influence the sulfonamide testing properties of the media/peptones.

The observations that the solutions of peptones/media produced growth zones in a test medium (Folic Acid Assay PGA Broth) containing no FA, and zones of growth inhibition in the same test medium enriched with small amounts of FA, are difficult to explain. The growth zones may be produced by folic acid active components other than FA and one possibility is the presence of inhibitory substances, specific for FA, causing the zones of growth inhibition. 
The gel filtration of the media/peptones showed that the inhibitors had molecular weights below 500 . The antagonism may be caused by structural analogues of FA, similar to the FA antagonists detected by Nichol et al. (1953). In this case, the presence of these inhibitors in the media may reduce the effect of antisulfonamide substances such as p-aminobenzoic acid and folic acid.

The peptones tested in this investigation are manufactured in different ways, but the available information about the processes are scarce. Consequently there is no basis for a discussion whether the method of production is of importance for the suitability of a medium for sulfonamide testing.

\section{CONCLUSIONS}

The following conclusions of practical interest for the bacteriologists may be drawn from this investigation:

1. The factors affecting the sensitivity of a sulfonamide test medium are p-aminobenzoic acid, folic acid and derivates of these substances.

2. The content of inhibitors of folic acid or of other sulfonamide antagonists may influence the suitability of the media.

3. Paper Disc Method-Antibiotic Sensitivity Medium, Mueller Hinton medium and Sulphonamide Antagonist Free medium seem to be the best synthetic media for sulfonamide testing procedures.

4. None of the peptones examined in this work should be used in media for sulfonamide susceptibility tests.

Addition of yeast extract cannot be recommended in such media.

5. For resistance determinations PDM, SAF and MH are satisfactory. However, for detection of residues of sulfonamides these three media are not sufficiently sensitive.

6. Acetobacter medium is found to be a better medium for this purpose when using Bacillus megaterium as test organism.

\section{REFERENCES}

Anonymous: Biodisk information scrvice. AB Biodisk, Stockholm, Sweden 1973.

Anonymous: Difco Manual, Ninth Edition. Difco Laboratories, Inc., Detroit, USA 1953.

Anonymous: Information from A/S Orthana Kemisk Fabrik, Copenhagen, Denmark 1973. 
Anonymous: Oxoid Manual, Third Edition. Oxoid Ltd., London, England 1969.

Anonymous: Pre-weighed dehydrated culture media. Mast Laboratories, Liverpool, England 1972.

Anonymous: Sephadex $\AA$ Gel filtration in theory and practice. Pharmacia Fine Chemicals AB, Uppsala, Sweden 1972.

Cooperman, J. M.: Microbiological assay of folic acid activity in serum and whole blood. In Colowick, S. P. \& N. O. Kaplan, eds.: Methods in Enzymology, Acad. Press, New York and London $1971,18 B, 629-642$.

Eigen, E. \& G. D. Shockman: The folic acid group. In Kavanagh, F., ed.: Analytical Microbiology, Acad. Press, New York and London $1963,1,431-488$.

Ericsson, H. M. \& J. C. Sherris: Antibiotic sensitivity testing. Report of an international collaborative study. Acta path. microbiol. scand. 1971, section B, suppl. 217, 1-90.

Ford, J. E., D. N. Salter \& K. J. Scott: The folate-binding protein in milk. J. Dairy Res. 1969, 36, 435-446.

Gudding, R. \& I. Hellesnes: Påvisning av sulfonamider i melk. (Detection of sulfonamides in milk). Nord. Vet.-Med. 1973, 25, $248-255$.

Hitchings, G. H. \& J. J. Burchall: Inhibition of folate biosynthesis and function as a basis for chemotherapy. Advanc. Enzymol. 1965, $27,417-468$.

Landy, M. \& D. M. Dicken: A microbiological method for the determination of p-aminobenzoic acid. J. biol. Chem. 1942, 146, $109-114$

Mueller, J. H. \& J. Hinton: A protein-free medium for primary isolation of the gonococcus and meningococcus. Proc. Soc. exp. Biol. (N. Y.) 1941, 48, 330-337.

Nichol, C. A., S. F. Zakrzewski \& A. D. Welch: Resistance to folic acid analogues in a strain of Streptococcus faecalis. Proc. Soc. exp. Biol. (N. Y.) 1953, 83, $272-277$.

Read, R. B., jr., J. G. Bradshaw, A. A. Swartzentruber \& A. R. Brazis: Detection of sulfa drugs and antibiotics in milk. Appl. Microbiol. 1971, 21, 806-808.

Rose, S. B. \& B. Snyder: "All or none" antibacterial disc test in synthetic medium. Amer. J. clin. Path. 1971, 56, 667-675.

Tsukahara, T. \& M. Yamada: Microbiological assay of folate by thinlayer cup-plate method with Streptococcus faecalis. In Colowick, S. P. \& N. O. Kaplan, eds.: Methods in Enzymology, Acad. Press, New York and London 1971, 18 B, 642-652.

Weygand, F., A. Wacher, A. Trebst \& O. P. L. Swoboda: Uber die Biosynthese der Folsäure. (On the biosynthesis of folic acid). $Z$. Naturforsch. 1956, $11 \mathrm{~B}, 689-693$. 
Woods, $D$. D.: The relation of p-aminobenzoic acid to the mechanism of the action of sulphonamide. Brit. J. exp. Path. 1940, 21, 7490.

Yndestad, M.: Personal communication 1973.

\section{SAMMENDRAG}

Brukbarheten av enkelte medier og peptoner til unders $\phi k e l s e$ av sulfonamider.

Innholdet av p-aminobenzoesyre og folinsyre er blitt unders $\emptyset \mathbf{k t}$ i enkelte medier og peptoner, og følsomheten av Bacillus megaterium dyrket på disse substratene overfor sulfonamider er blitt unders $\varnothing \mathrm{kt}$.

Lavest mulige konsentrasjoner av p-aminobenzoesyre og folinsyre er vesentlig for brukbarheten av de enkelte substratene, men andre faktorer virker også inn. Det er vist at enkelte medier inneholder antagonister overfor folinsyre, og betydningen av slike inhibitorer er diskutert.

Tre av de undersøkte mediene (Paper Disc Method-Antibiotic Sensitivity Medium, AB Biodisk; Sulphonamide Antagonist Free Medium. Mast Laboratories; og Mueller Hinton, Difco Laboratories) synes a være tilfredsstillende ved resistensbestemmelse av bakterier overfor sulfonamider. Acetobacter medium er foreslått benyttet ved påvisning av restkonsentrasjoner av sulfonamider i næringsmidler.

(Received February 11, 1974).

Reprints may be requested from: Roar Gudding, Department of Food Hygiene, Veterinary College of Norway, Postbox 8146, Oslo-Dep., Oslo 1, Norway. 